Issued by Sandia National Laboratories, operated for the United States Department of Energy by Sandia Corporation.

NOTICE: This report was prepared as an account of work sponsored by an agency of the United States Government. Neither the United States Government, nor any agency thereof, nor any of their employees, nor any of their contractors, subcontractors, or their employees, make any warranty, express or implied, or assume any legal liability or responsibility for the accuracy, completeness, or usefulness of any information, apparatus, product, or process disclosed, or represent that its use would not infringe privately owned rights. Reference herein to any specific commercial product, process, or service by trade name, trademark, manufacturer, or otherwise, does not necessarily constitute or imply its endorsement, recommendation, or favoring by the United States Government, any agency thereof, or any of their contractors or subcontractors. The views and opinions expressed herein do not necessarily state or reflect those of the United States Government, any agency thereof, or any of their contractors.

Printed in the United States of America. This report has been reproduced directly from the best available copy.

Available to DOE and DOE contractors from

Office of Scientific and Technical Information

P.O. Box 62

Oak Ridge, TN 37831

Prices available from (703) 605-6000

Web site: http://www.ntis.gov/ordering.htm

Available to the public from

National Technical Information Service

U.S. Department of Commerce

5285 Port Royal Rd

Springfield, VA 22161

NTIS price codes

Printed copy: A03

Microfiche copy: A01

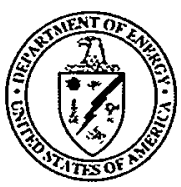




\section{DISCLAIMER}

Portions of this document may be illegible in electronic image products. Images are produced from the best available original document. 
SAND99-1941

Unlimited Release

Printed August 1999

\title{
A HISTORY OF BUILDING 828, SANDIA NATIONAL LABORATORIES
}

\author{
Rebecca Ullrich \\ Albuquerque Staff Augmentation Providers \\ 7831 Marble, N.E. \\ Albuquerque, NM 87110 \\ Sandia Contract No. SA-0004A
}

\begin{abstract}
This report documents the history of Building 828 in Sandia National Laboratories' Technical Area I. Building 828 was constructed in 1946 as a mechanical test laboratory for Los Alamos' Z-Division (later Sandia) as it moved to Sandia Base. The building has undergone significant remodeling over the years and has had a variety of occupants. The building was evaluated in compliance with the National Historic Preservation Act, but was not eligible for the National Register of Historic Places. Nevertheless, for many Labs employees, it was a symbol of Sandia's roots in World War II and the Manhattan Project.
\end{abstract}




\section{Acknowledgments}

I would like to thank Jerry Burling and Doug Kaczmarek of Mason \&

Hanger-Silas Mason Company at Pantex for providing clarification of the 1945 military regulations governing the handling of high explosives. I am also grateful to Jim Knecht and John Herron of Sandia organization 4912 for research assistance. 


\section{Contents}

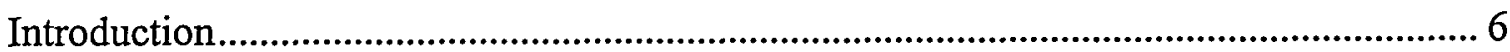

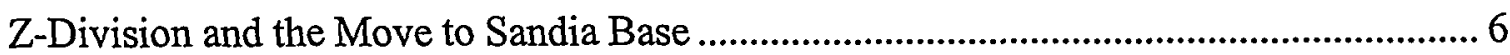

Construction and Early Occupants.......................................................................... 8

Changing Purpose and Remodeling................................................................................ 16

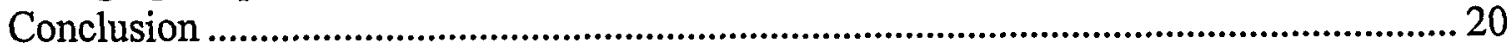

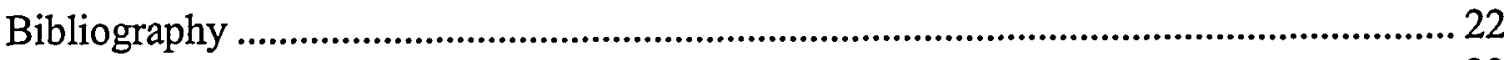

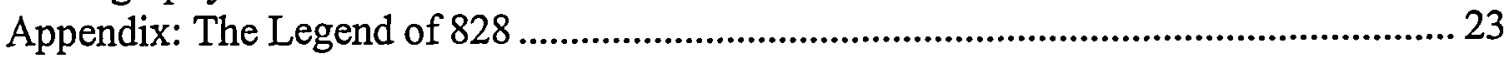

\section{Figures}

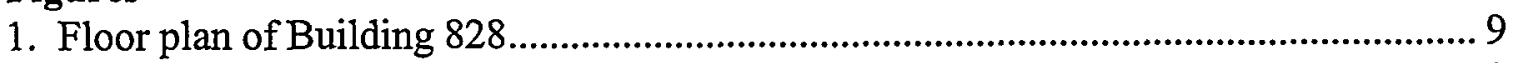

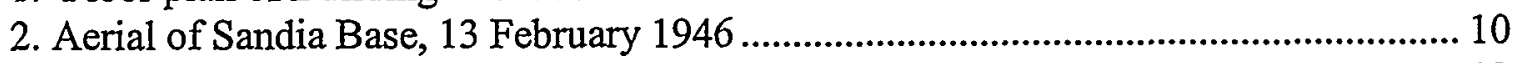

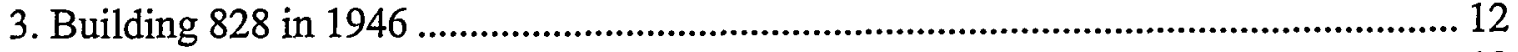

4. York cold chamber in Building 828, 1950..................................................................... 13

5. Laboratory equipment of the mechanical test group, 1949............................................ 14

6. Looking west in the interior of Building 828's second story ......................................... 17

7. Joining equipment...................................................................................................... 18

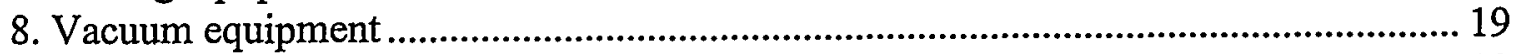

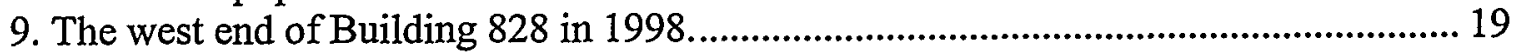

10. Aerial of Sandia New Mexico.................................................................................. 20

11. Demolition of Building 828, 1999........................................................................... 21 


\section{A History of Building 828, Sandia National Laboratories}

\section{Introduction}

Sandia National Laboratories (SNL) is a national security laboratory currently operated for the U.S. Department of Energy (DOE) by the Sandia Corporation, a Lockheed Martin Company. Sandia has its roots in World War II's Manhattan Engineer District, the project that designed, tested, and produced the first nuclear weapons. Sandia's precursor was Los Alamos's Z-Division, created in July of 1945 to perform the ordnance engineering and assembly activities related to Los Alamos' design work. In the late fall of 1945, some units of Z-Division began to move to Sandia Base near Albuquerque. To house Z-Division activities, several buildings were brought from other Manhattan Project sites while planning for new facilities was underway.

Building 828 in Sandia National Laboratories' Technical Area I was built in 1946 as a mechanical test laboratory. As such, it played a key support role in the design and testing mission of Z-Division. Weapon prototypes and components were subjected to a variety of environmental tests in the building, which was equipped with an extensive array of test facilities.

Building 828 was the last remaining of the first four buildings originally constructed for Z-Division. All four were considered temporary structures when they were built, but remained in use for decades as other, permanent, structures rose around them and their original occupants moved to more desirable quarters. Building 828 has, for the better part of the last decade, been considered largely uninhabitable and SNL programs maintained personnel in it only until they could find more suitable space. The building stood empty for three years and was demolished in the late spring of 1999 . It is thus appropriate to document its history now.

\section{Z-Division and the Move to Sandia Base}

At the end of World War II, the United States had no clear policy for its newfound nuclear capability and spent the next few years creating both policies and the agencies to implement them. Nevertheless, Los Alamos Director J. Robert Oppenheimer and the Manhattan Engineer District's military personnel made a concerted effort to keep nuclear weapon design and development efforts moving forward as the nation made the transition to peace. Until 1 January 1947, when the Atomic Energy Commission took over the management of America's nuclear energy concerns, work related to nuclear weapons continued to be done under the auspices of the Manhattan Engineer District.

In June of 1945, Los Alamos' management began looking for a new home for nuclear weapon engineering activities, especially the field testing and weapon assembly operations. Los Alamos was crowded and suffered periodic water and other utility 
shortages. In addition, materials and equipment had to be trucked to and from the airfield in Albuquerque or the rail depot in Lamy, New Mexico. The airfield in Wendover, Utah, which served as the headquarters of the $509^{\text {th }}$ Composite Group-responsible for testing weapon shapes and training for weapon drops-was inconveniently far from Los Alamos. Instead, a site adjacent to Kirtland Field, near Albuquerque, was chosen. East of Kirtland Field were the remains of the old municipal Oxnard airfield. Known as Sandia Base, the site had been a convalescent center for wounded airmen in 1944 and was used as a dismantlement center for surplus aircraft immediately after the war. ${ }^{1}$

Z-Division was created at Los Alamos in July of 1945 to perform ordnance engineering and assembly activities. The creation of Z-Division was part of Oppenheimer's attempt to plan for the postwar period. Amid the final rush to prepare the Little Boy and Fat Man bombs for use in the summer of 1945, Oppenheimer began to look beyond the war's emergency efforts for a way to place the development and production of nuclear weapons on a more stable footing. Postwar planning was not a high priority before the war had actually ended, however, and not much happened with ZDivision for several months.

In August of 1945, Z-Division head Jerrold Zacharias prepared an outline of ZDivision's proposed organization, suggesting sub-divisions in charge of Experimental Systems Engineering, Assembly Factory and Procurement (including weapon assembly), Electrical Engineering, Mechanical Engineering for Production, and Electronic Engineering. Basically, Z-Division was responsible for the design and production of nearly all non-nuclear components of nuclear weapons.

On August 20, 1945 Oppenheimer formally announced that Z-Division had absorbed much of the engineering activity associated with nuclear weapons. The military pushed for more details.

There having been no formal announcement of the functions of " $Z$ " Division, a conference on 21 August with Mr. Oppenheimer was arranged to ascertain these responsibilities. It was learned that the " $Z$ " Division was to proceed with the assembly of a stock pile (less plutonium) and such additional units as would be required for development and surveillance tests. The new division was further to assume full responsibility for the

\footnotetext{
'For a thorough discussion of Z-Division's move to Albuquerque and Sandia's early history, see Necah Furman, Sandia National Laboratories: The Postwar Decade (Albuquerque: University of New Mexico Press, 1990); a shorter overview of Sandia's history is presented in Leland Johnson, Sandia National Laboratories: A History of Exceptional Service in the National Interest (Albuquerque: Sandia National Laboratories, 1997); and for a summary of the early history of Kirtland Air Force Base, see Don E. Alberts and Allan E. Putnam, A History of Kirtland Air Force Base 1928-1982 (Albuquerque: Kirtland Air Force Base, 1982).
} 
design, test, and production of new models, with the exception of HE components and the active materials....

These activities remained Z-Division's main responsibilities and they continued, with some modification, to define Sandia's mission in its early decades.

\section{Construction and Early Occupants}

Building 828 was built specifically to house mechanical test activities related to the design of new weapons. These activities were to be performed by Group Z-6, the mechanical test group, which had first to create its own laboratory. In early October, William T. Theis, the group's first leader, said Z-6 was to "design, install and operate a mechanical test laboratory to subject the weapon and/or its components to all conditions that will be encountered from the time the weapon is assembled until the time its drop has been completed."3

Theis went on to assign individual responsibilities within the group, placing Grant Clive in charge of the laboratory equipment and building design work. ${ }^{4} \mathrm{~A}$ group of men reported to Clive, performing the design functions. The result was Building 828, placed near the north edge of the Z-Division technical area on Sandia Base, at the northwest corner of what is now the intersection of $G$ Avenue and $7^{\text {th }}$ Street. Among the designers was Virgil Harris, who later spoke to Sandia historian Ted Alexander of his role in designing 828. Alexander's notes summarize their conversation.

Building 828 was designed by Harris at Los Alamos during the summer of 1945. The plans were sent down to the Sandia Post Engineer (who was Luther Heilman at the time) for construction. ${ }^{5}$

Architectural drawings for Building 828 created by the Office of the Post Engineer, Sandia Base in December of 1945 and January 1946 clearly indicate that the building was designed to be a mechanical test laboratory. ${ }^{6}$ Figure 1 is a sketch of the original floor plan. The building was designed as a large, uneven $\mathrm{H}$, with the long sides running east to west. The north section was shorter and narrower, designed with office space at the west end and a large drafting room at the east. The longer south section, the core of the mechanical test laboratory, housed mechanical test equipment. The shorter

\footnotetext{
${ }^{2}$ Captain R. A. Larkin to Commodore Parsons, memorandum, 7 September 1945, p. 1, Collection 310.1 Organization, Los Alamos Archives; copy in Collection 69, Box 3, Correspondence and Documentation on Sandia's History, SNL Archives.

${ }^{3}$ W. T. Theis to J. R. Zacharias, memorandum, 1 October 1945, Collection 310.1, Los Alamos Archives; copy in Los Alamos Correspondence: October 1945 file, Collection 71, Box 2, Origins of Los Alamos, SNL Archives.

${ }^{4}$ Ibid.

${ }^{5}$ Virgil Harris, telephone interview by Ted Alexander, 26 September 1960, notes in Documents used in Leland Johnson's history file, Collection 96, F. C. Alexander Collection, Box 2, SNL Archives.

${ }^{6}$ Architectural drawings 97708, sheets 1-5, copies in Building 828 Collection, SNL Archives.
} 


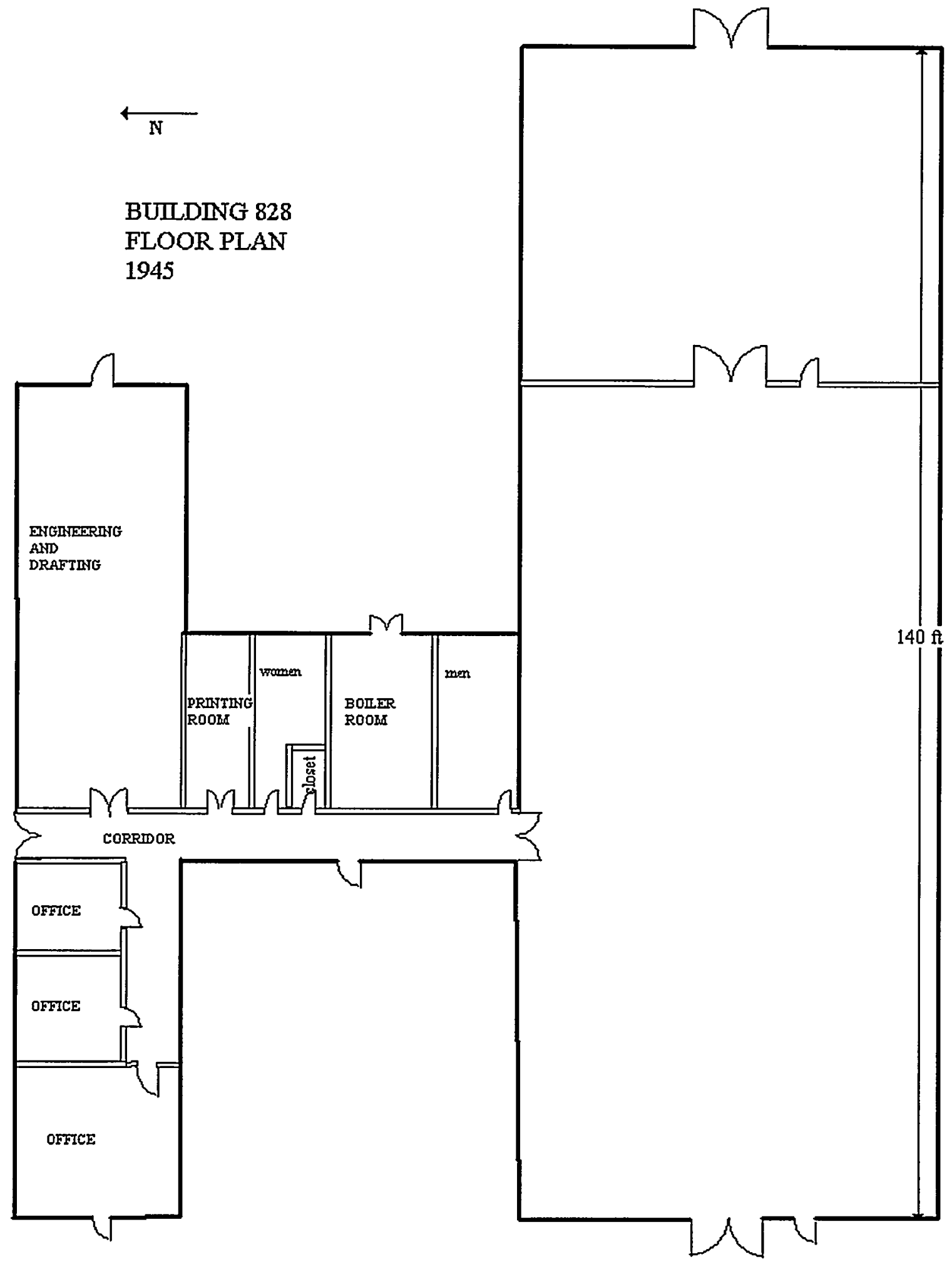

Figure 1. Floor plan of Building 828 based on the 1945 design. 
connecting bar of the $\mathrm{H}$ held the restrooms, boiler room, and a small printing room with an ozalid printer.

As a temporary building in the military style of the period, Building 828 was wood framed, with steel framing in the south section to support the $1 / 2$-ton monorail and hoist that protruded from the building's west end. Each section of the building had a pitched roof, with a partial second story on the south section. The second level originally was not separated from the first, serving instead as a high bay within the building, allowing the monorail sufficient height. The building enclosed 10,120 square feet.

Construction and obtaining appropriate laboratory equipment took some time. Figure 2 is an aerial photograph of the north end of the Sandia technical area (as well as some of the base housing and airplanes scheduled for postwar destruction) in February 1946. Building 828 is clearly under construction just to the south (left) of the Base Chapel. The north section and crossbar are framed and roofed, but framing on the south section has just begun. Visible as a dark smudge about halfway along the left edge of the south section is the pit in the foundation to hold the cold chamber.

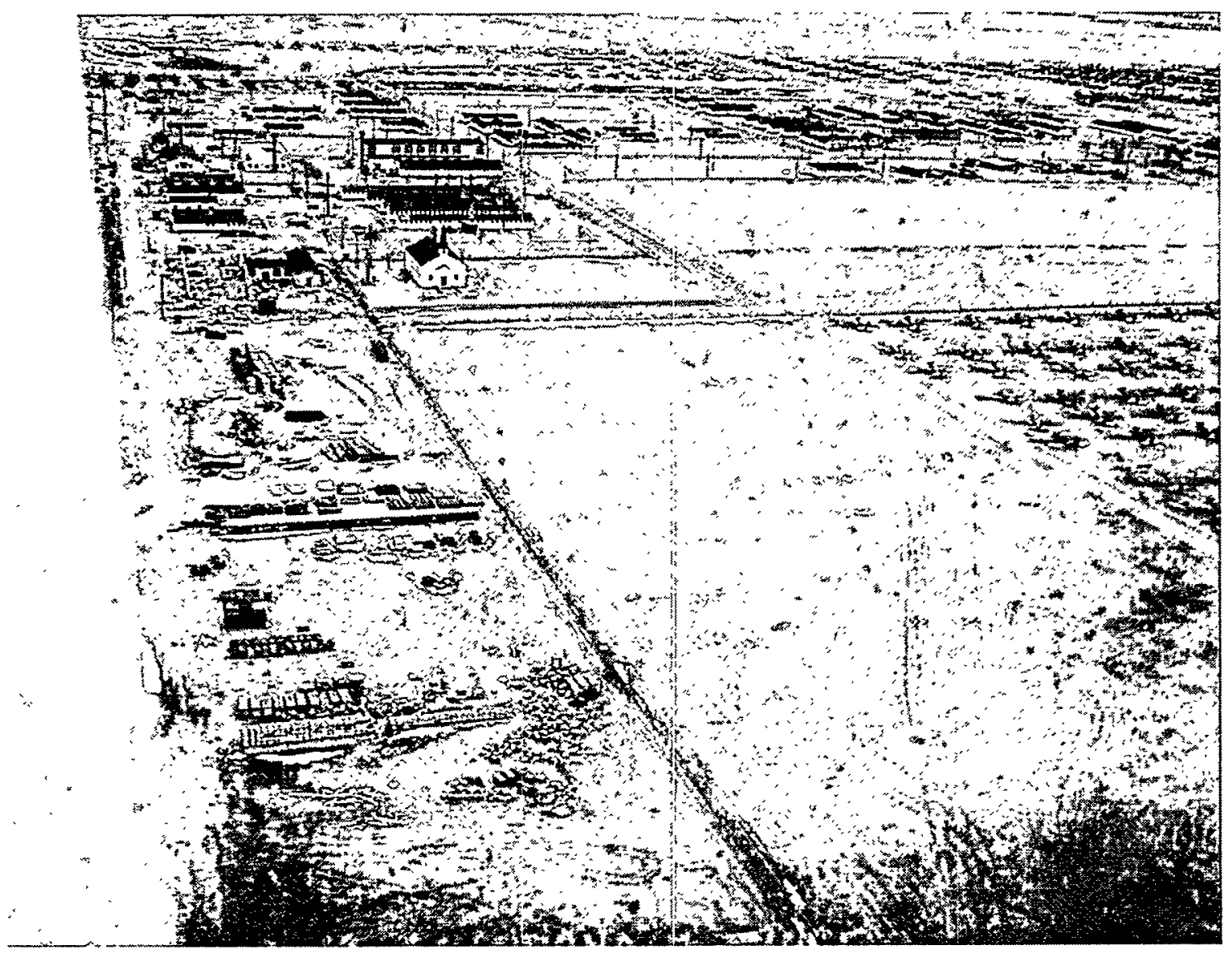

Figure 2. Aerial of Sandia Base, 13 February 1946. Building 828 is under construction just to the south (left) of the Base Chapel. ${ }^{7}$

\footnotetext{
${ }^{7}$ Photograph in Early Sandia Photographic Collection, SNL Archives.
} 
While the building was under construction, Group Z-6 proceeded with as much work as possible. By December, Alan Ayers and Harlow Russ were co-leaders of the group and Roger Warner had replaced Zacharias as head of Z-Division (in October). In a memorandum to all group leaders, Warner identified the immediate responsibilities of each group, including Z-6.

Messrs. Ayers and Russ (Z-6) are responsible to this office for bringing all the mechanical components up to the latest specification, supplying spare mechanical parts and handling equipment kits.

Messrs. Ayers and Russ (Z-6) will initiate at once the procurement of 40-1561 spheres, assembled and packed for storage. These units will include merely the spheres plus cork 2" booster holes, ... These units should be stored at Sandia by 1 June under the category of experimental firing groups at Los Alamos. ${ }^{8}$

In April 1946, the building appeared to be nearing completion and by 3 June was pronounced "complete except for one floor slab and connections to mechanical equipment not received." 9 Once the building itself was complete, there were still personnel shortages due to the support of Operation Crossroads, the first postwar nuclear test, held in the Pacific in the summer of 1946. Further, as Dale Corson, acting as ZDivision leader while Roger Warner attended Crossroads, reported, equipment was slow to arrive.

The Mechanical Testing Laboratory, which Z-6 has been building, is gradually becoming an operating unit. We have no large shake table yet, and the prespect [sic] of getting one in the near future is not too bright. However, we have smaller shake tables in operation. Our large York cold chamber is not yet operating, but it should be within the next few weeks. Our smaller Tenney cold chamber operates, but not satisfactorily. Group Z-6 also operates a drafting room and machine shop which is available to all Z Division groups at Sandia. Z-6 also maintains a file of all Sandia $Z$ Division tracings. ${ }^{10}$

Certainly Z-6 was not the only group to proceed more slowly than anticipated due to Crossroads and construction problems. Nearly every Z-Division report to Los Alamos reflects some frustration with personnel and space shortages, as well as a nagging lack of

\footnotetext{
${ }^{8}$ Roger S. Warner, Jr. to Capt W. F. Schaffer, Lt. Col. E. E. Wilhoyt, Lt. Col. A. J. Frolich, Mr. Glenn Fowler, Mr. Alan Ayers, Mr. Harlow Russ, Col. A. W. Betts, memorandum, 16 December 1945, pp. 2-3, Collection Parsons 400.211, Los Alamos Archives; copy in file: Los Alamos Correspondence: NovemberDecember 1945, Collection 71, Box 3, Origins of Los Alamos, SNL Archives.

${ }^{9}$ George R. Hawthorne to Commanding Officer, U.S. Engineers, attention: Lt. Col. W. A. Stevens, 3 June 1946, Collection A-84-019 18-8, Los Alamos Archives.

${ }^{10}$ Dale R. Corson to N. E. Bradbury, memorandum, 28 June 1946, Collection A-84-019 7-3, Los Alamos Archives.
} 
equipment. Still, Z-6 did have its building and enough equipment operating to be consistently lauded in those same reports.

Figure 3 shows Building 828 as it appeared in 1946. The photograph was taken looking to the northeast, showing the west ends of the building. The monorail and hoist enter the west end of the building's south section through double doors, wider at the bottom than the top. The pitched roof running north-south about halfway down the south section (on the far right side of the photograph) formed a high bay where pendulum experiments could be conducted.

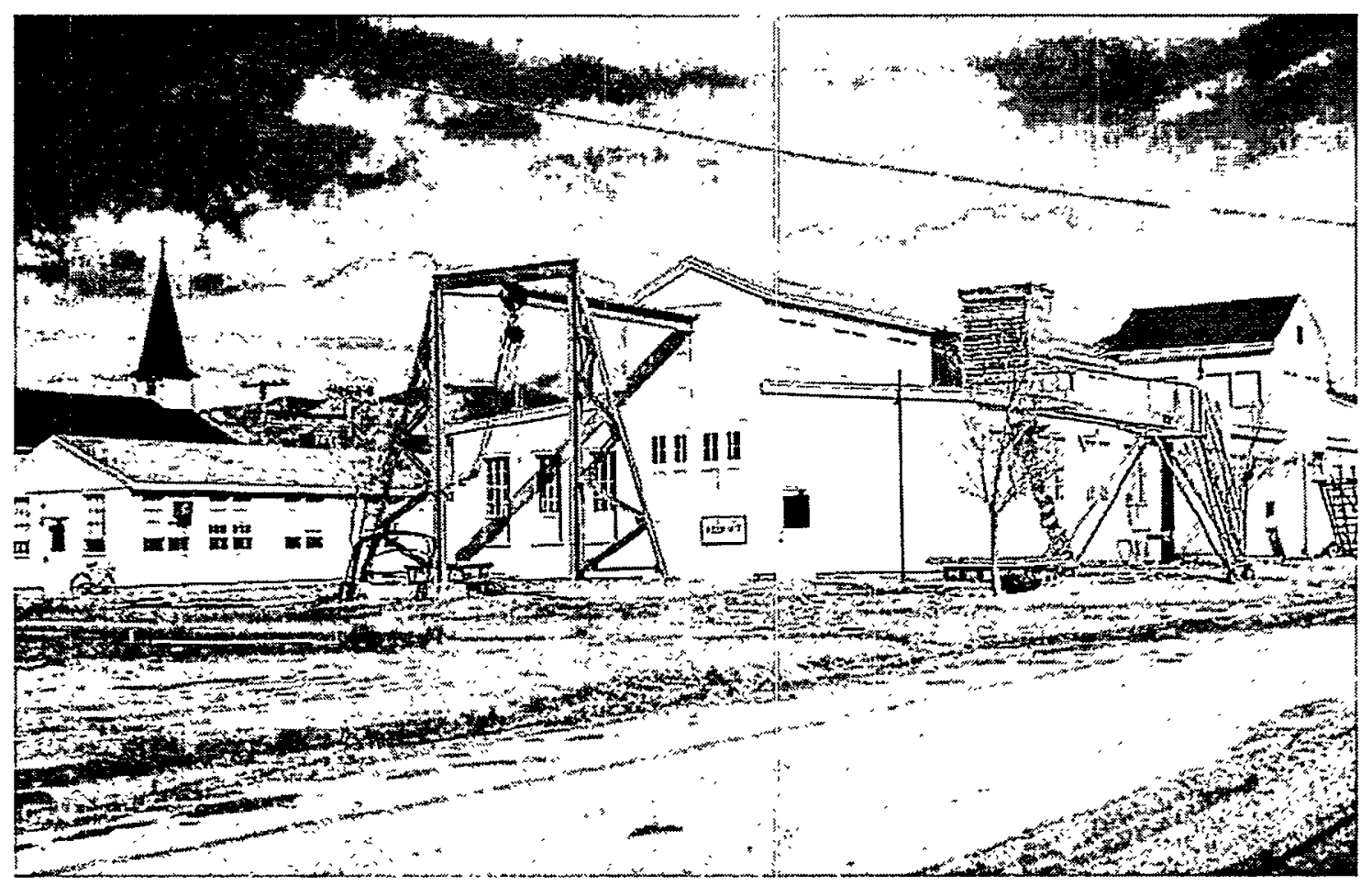

Figure 3. Building 828 in 1946. Photograph looking northeast at the west end of the south section, with the north section at far left. The Base Chapel is visible in the left background. ${ }^{11}$

Building 828 was used almost exclusively as a mechanical test laboratory until 1950. The group focused on a variety of tasks subjecting weapons and their components to a range of environmental conditions to understand and improve weapon behavior. Shake tables and cold chambers were installed. Figure 4 is a photograph of the York cold chamber used to subject weapon components and prototypes to severe environmental conditions.

\footnotetext{
"Still Photo Collection, SNL Archives.
} 


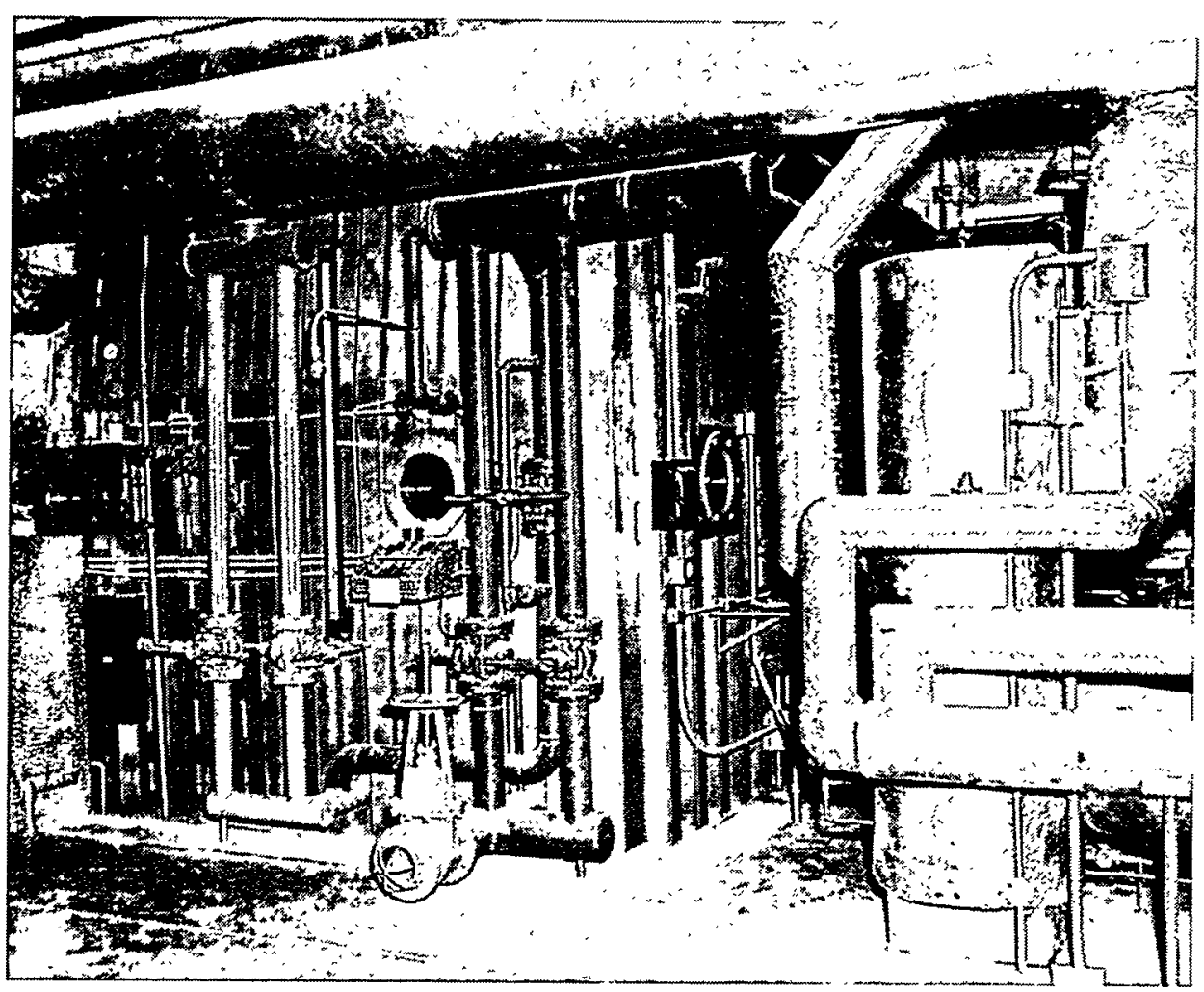

Figure 4. York cold chamber in Building $828,1950 .{ }^{12}$

In 1947, the mechanical test group reported on a range of work conducted in Building 828. Their efforts included tests to determine the most rugged thermostat to control temperatures in a weapon, calibrating devices, weighing electrical components, vibration tests on a number of components, computing the volume of air in each weapon, and undertaking development tests for other Z-Division groups. ${ }^{13}$ The group also contributed to the design of components and had its own machine shop and model makers in the building. ${ }^{14}$ Figure 5 is a photograph of the interior of Building 828's south section, which housed the mechanical test laboratory. It indicates the impressive array of laboratory equipment used by the group by 1949; pipes for the cold chamber are visible on the left side of the photo.

\footnotetext{
${ }^{12}$ Negative D9691, Still Photo Collection, SNL Archives.

${ }^{13}$ Summaries of Group Z-6 achievements are included in declassified portions of the Z-Division progress reports sent to Los Alamos. See "Z-Division Progress Report, 18 June 1947 to 18 July 1947," "Z-Division Progress Report, 18 July 1947 - 18 August 1947," "Z-Division Progress Report, August 21 - September 20,1947 ," all on Archive Reel 1513, beginning on pages 208, 271, and 340 respectively, Central Technical File, SNL Technical Library.

${ }^{14}$ Alan Ayers interviewed by Leland Johnson, videotape, 25 October 1995, SNL Archives.
} 


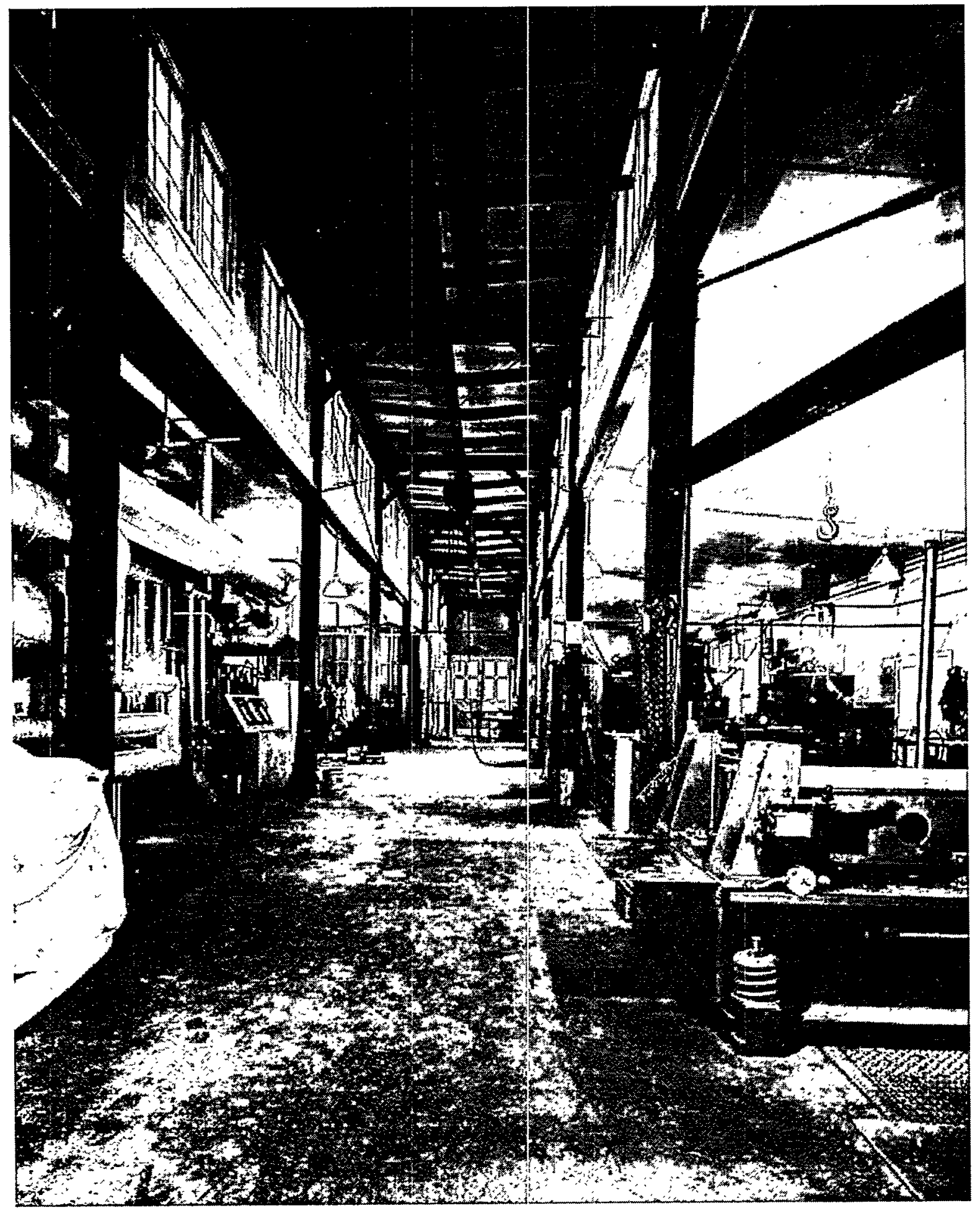

Figure 5. Laboratory equipment of the mechanical test group, $1949 .{ }^{15}$

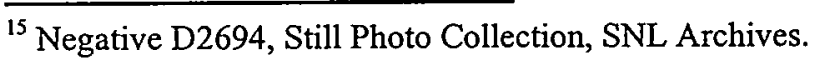


As the group's tasks increased, so did the amount of equipment and space they required. Early in 1947 the roof of the pendulum bay in the south section of Building 828 was raised to allow for moment of inertia determinations on full-scale weapon units. ${ }^{16}$ In March of 1947, the group reported it had run the first such test on a Mk IV bomb that had been disassembled and mocked-up for the test. ${ }^{17}$

Minor remodeling was not sufficient, however. By April of 1947, plans were started to design a new mechanical test laboratory building. ${ }^{18}$ The new building's layout and the specifications for new equipment were complete by June and procurement for some of the new items was underway. This was a long process, however, and the group's responsibilities continued to grow, requiring revisions in the plans for the new, larger building, as Z-Division leader Paul Larsen indicated early in 1948.

Z-6 laboratory plans have been modified to include complete metallurgy and standards laboratory facilities. Considering these modifications, the working floor space for the new building would cover 42,000 sq. $\mathrm{ft}^{19}$

The new Building 860 was not built until 1949, and Building 828 became quite crowded. Operation Sandstone, a new series of weapon tests, was planned for the spring of 1948, and again drew personnel away from ongoing concerns at Sandia Base and caused crowding within the tech area. By November of 1947, approximately $30 \%$ of Group Z6 's floor space had been taken over for various Sandstone preparations. ${ }^{20}$ In the meantime, Group Z-6 went looking for work and received the praise of prominent physicist John Manley, who provided a report on Z-Division to the Atomic Energy Commission late in 1947.

The group (Z-6) has found time to survey literature, consider the problem and compile a report (SMD-284) on an earthpenetrating weapon. Further work is being held in abeyance pending high level decision on urgency.

The group is anxious to look to future work along [these] lines ... It appears to be in such a position that this should be encouraged. $^{21}$

\footnotetext{
${ }^{16}$ Architectural drawing 97708, sheet 6, 26 February 1947 indicates how the small section of roof halfway down the south section of Building 828 was raised slightly to accommodate the steel A-frame of the heightened pendulum device. The frame was removed during remodeling in 1949 according to architectural drawing 85767, sheet 1,1949. Copies of both drawings are in the SNL Archives.

${ }^{17}$ The high explosive was replaced with inert material and telemetry equipment was installed. The test is reported in "Z-Division Progress Report, 21 March 1947 - 20 April 1947," Archive Reel 1513, Central Technical File, SNL Technical Library.

${ }^{18}$ Ibid.

${ }^{19}$ P. J. Larsen to N. E. Bradbury, Z-Division Status Report - Abstract, 27 January 1948, p. 8, Archive Reel 1513, Central Technical File, SNL Technical Library.

20 "Status Report for Z-Division - Abstract, 19 October 1947 - 19 November 1947," Archive Reel 1513, Central Technical File, SNL Technical Library.

${ }^{21}$ J. H. Manley, "Report on Z-Division," prepared for the General Advisory Committee, 10 November 1947, p. 8, Collection 310.1 "Z" 1/47 thru 11/48, Los Alamos Archives.
} 
Building 828 witnessed the creation and growth of a very dynamic group performing a variety of essential technical support functions before it proved too small for mechanical testing.

On April 1, 1948, Z-Division was reorganized. It was elevated to a separate branch of Los Alamos, named Sandia Laboratory, Branch of Los Alamos. Under Paul Larsen, the laboratory underwent substantial expansion. Twenty-eight buildings were planned for fiscal years 1948, 1949, and 1950 and the laboratory was able to focus completely on its work, less distracted by concerns about space.

Sandia's expansion and emphasis on ordnance engineering did not please the University of California, which held the management contract for Los Alamos and, hence, for Sandia. After a variety of proposals had been explored, AT\&T replaced the University of California as contract manager for Sandia. Sandia Corporation, a wholly owned subsidiary of Western Electric (AT\&T's manufacturing arm) was formed on October 5,1949 . On November 1, 1949, the new corporation took over the management contract and Sandia became a Laboratory separate from Los Alamos. Paul Larsen left and George Landry was appointed the first president of Sandia Corporation.

\section{Changing Purpose and Remodeling}

As mechanical and environmental test activities began to outgrow Building 828 , the building was remodeled in an attempt to accommodate their needs while they waited for new sites. In 1949, the building underwent a major renovation to fill in the $\mathrm{H}$ shape. The areas between the north and south sections were filled in with additional offices and equipment space.

The environmental test activities moved to Building 860 between 1952 and 1953, while all of Sandia's shop activities were consolidated in Building 840 in $1951 .^{22}$ From that point on, Building 828 primarily housed groups involved in instrument development and testing. The test instrument division moved into Building 828 in 1953. The work in that group included instrument calibration and some optical development equipment work. In 1954 the group was renamed the telemetering division and it provided telemetry support for field test activities. Further instrumentation services were consolidated in the building in 1955, including the optical measurements division (photometrics).

Instrumentation services remained in the building until 1958, when it was again remodeled. The primary modifications were to renovate the restrooms, move partitions to accommodate new tenants, and rewire electrical circuits. ${ }^{23}$ The electronic test

\footnotetext{
${ }^{22}$ Much of the information on building occupancy is taken from the Sandia Phone Book Collection, SNL Archives; the move into Building 840 is also discussed in Paul Adams, interview by Necah Furman, 14 November 1983, p. 1, SNL Archives.

23 "Building 828 Modification Job to be Completed During Late February," Lab News, 28 November 1958, p. 1.
} 
equipment department (renamed system test equipment development department in 1960) moved into the building in 1959 from smaller quarters in Building 802. Building 828 offered more space for the large equipment used to design, fabricate, and test quality assurance systems test devices. ${ }^{24}$ While Building 828 had acquired different tenants in the course of the 1950s, it remained dedicated to testing and test equipment design.

In 1962, the building underwent significant remodeling to create new laboratories for component development. A drafting support area and a specifications and catalog library also were added. In 1963, the doors around the monorail were remodeled, the hoist was removed, and a new acoustical ceiling was installed below the monorail. The second story was thus completely separated from the first, creating a large, empty attic in the building. Figure 6 is a 1996 photograph of the interior of the second story, showing the boarded-up windows and the monorail still running through the area.

The technical library maintained a commercial catalogs branch and a specifications branch in the building until 1967, when restructuring consolidated them into one branch-engineering. In 1970, that branch moved into Building 804 where the main technical library was located. ${ }^{25}$

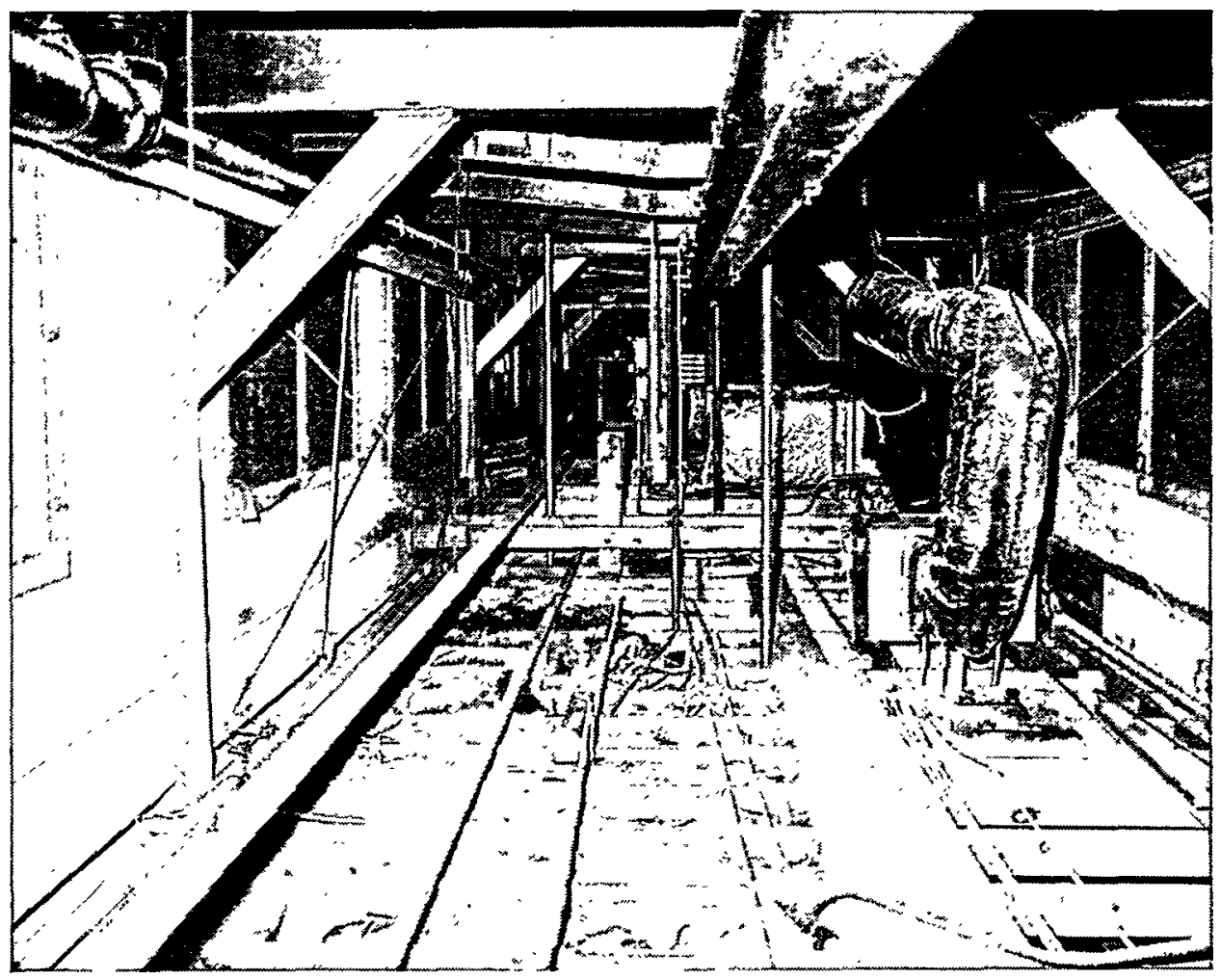

Figure 6. Looking west in the interior of Building 828 's second story. ${ }^{26}$

\footnotetext{
24 "Bids for Modification of Bldg. 828 Will Be Opened on Nov. 14," Lab News, 31 October 1958, p. 8. ${ }^{25}$ Lab News, 2 July 1970 , p. 6.

${ }^{26}$ Negative 30161, Still Photo Collection, SNL Archives. Photograph taken 1 February 1996 by Diana Helgesen, Sandia Photometric Department.
} 
In 1964, a centrifuge foundation and cage were installed in the northwest corner of the south section of the building. A variety of other equipment was installed and removed over time as different groups modified their research or moved out of the building altogether. Figures 7 and 8 show some of the equipment used by the electronic components groups. Equipment was also upgraded. For example, a new metal cage was installed around the centrifuge in 1974.

As the 1960 s progressed, the building was increasingly devoted to laboratory space. For example, in 1963 the advanced development section of the solid state and thin film devices division of the electronic components department moved into the building, conducting the microelectronics portion of their research in the building's labs. The microcircuit laboratory in the southeast portion of the building was modified in 1967 and the group stayed in the building until 1974.

In 1975, the transducer evaluation and calibration division moved into the building and the building came to be known as the transducer calibration and evaluation building. However, a variety of occupants still used the building. In the 1970s, the building began to house groups that needed laboratory space, but kept the majority of their employees in other facilities. For example, in 1973 two of the materials analysis divisions had laboratories in Building 828, but only four employees worked there; the rest were located in Building 805 .

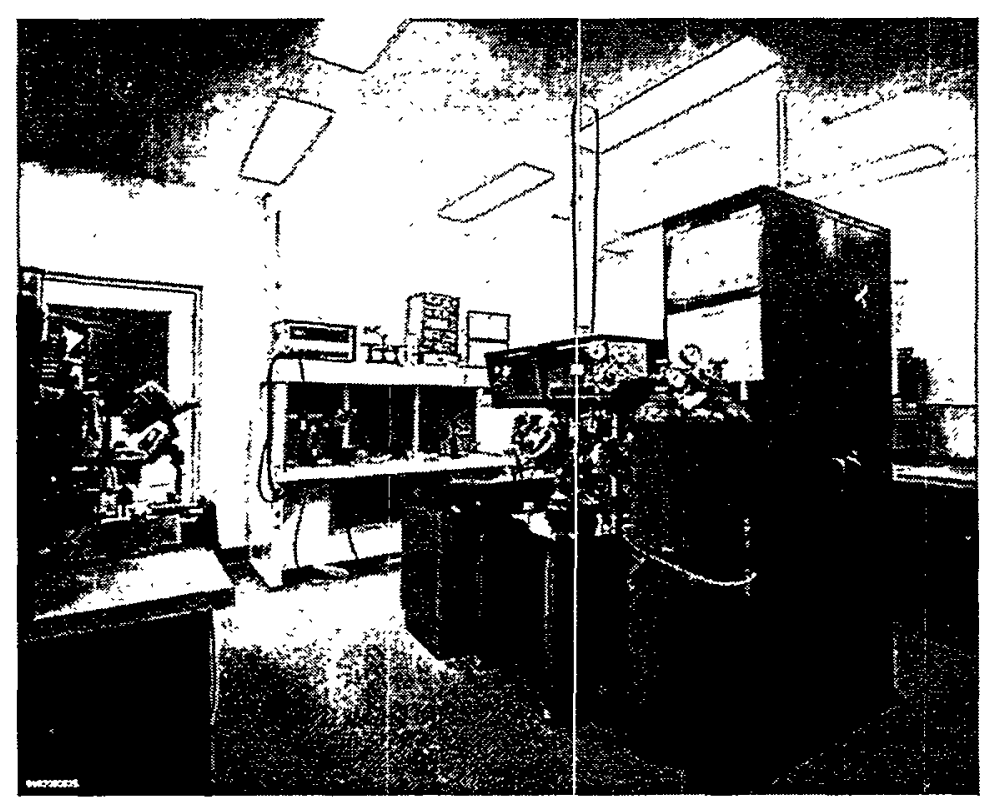

Figure 7. Joining equipment in Building $828,1969{ }^{27}$

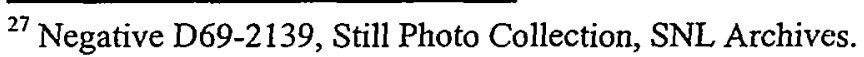




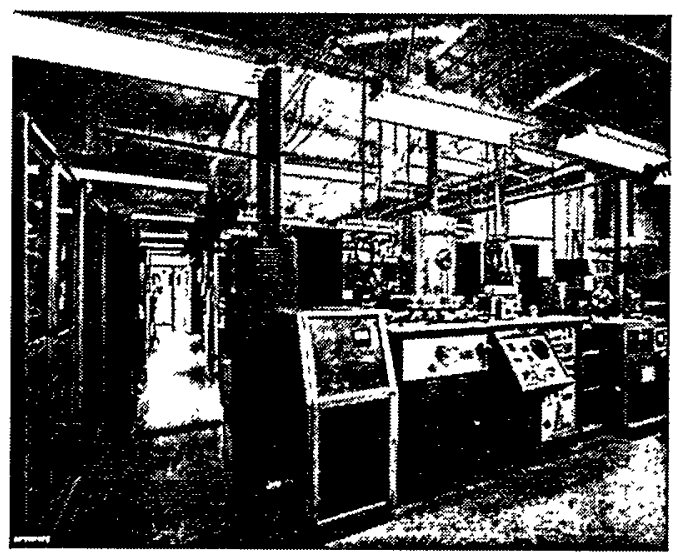

Figure 8. Vacuum equipment in Building $828,1969 .^{28}$

Building 828 was clearly seen as an inferior space by many organizations by the 1980s. New occupants did not stay long, moving on to better space as it became available. Underlining its undesirability, a photograph of Building 828 appeared as an example of a substandard structure in Sandia's 1989 Site Development Plan. ${ }^{29}$ The same document defines a substandard structure as a building "having a 10- to 29-year life.",30 Building 828 was already 43 years old at that time.

By 1992, there were only 12 people working in the building, none of them representing an entire organization. By June of 1996 the building was empty. Appropriately, the last spaces occupied in the building were the mechanical testing laboratories in the northeast part of the building. Figure 9 shows the west end of the building in 1998, when the building was clearly showing wear.

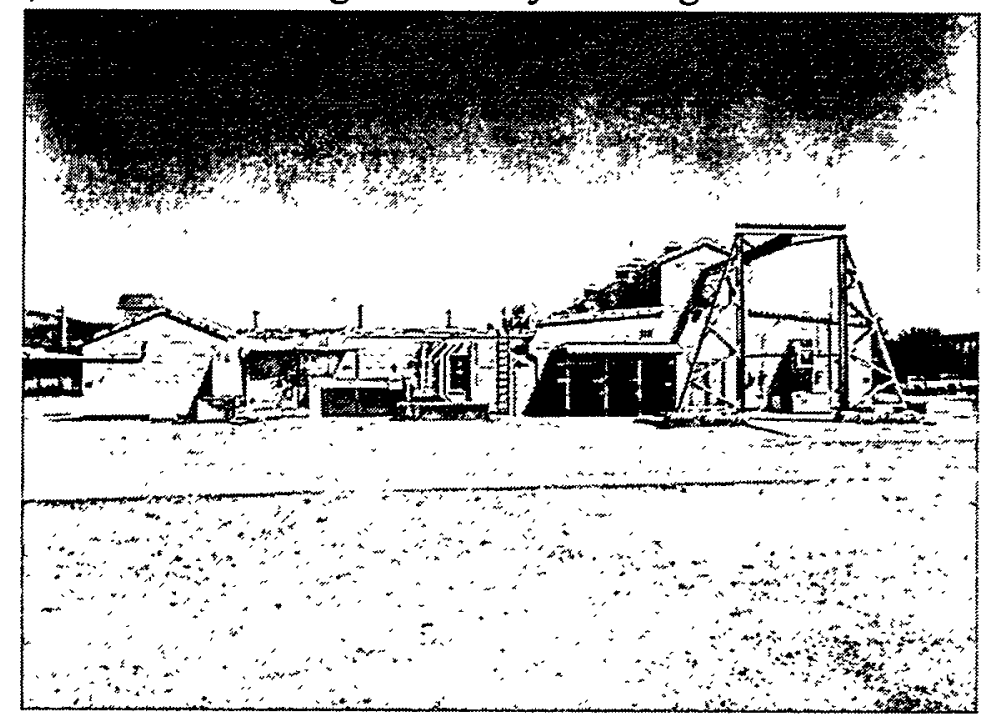

Figure 9. The west end of Building 828 in $1998 .^{31}$

\footnotetext{
${ }^{28}$ Negative D69-2138, Still Photo Collection, SNL Archives.

${ }^{29}$ Sandia National Laboratories, Site Development Plan (Albuquerque: Sandia National Laboratories, 1989), p. 116.

${ }^{30}$ Ibid., p. 114.

${ }^{31}$ Negative 30064, SNL Archives. Taken 14 April 1998 by Sandia photographer Walt Dickenman.
} 


\section{Conclusion}

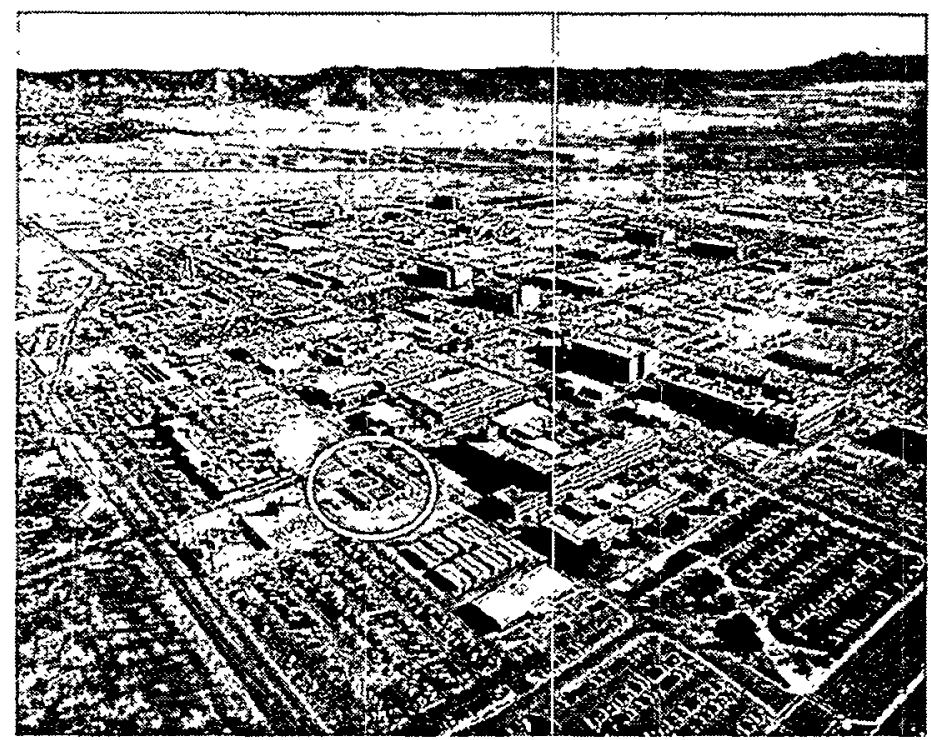

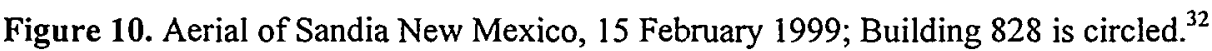

By 1999, Building 828 was 53 years old and looked quite worn. The buildings constructed around it in the past 50 years are made of brick or concrete, not wood. Its military design seemed out of place within the confines of Sandia's tech area.

Nevertheless, it served as a potent reminder of Sandia's origins.

From its original construction through its occupancy by various groups waiting for better space in its later years, Building 828 's history directly reflects the ongoing growth and change of Sandia. Built as a temporary structure, it was in use for fifty years because there was never enough space at Sandia. In spite of its many modifications, its exterior always reflected the World War II era in which it was conceived, while the series of upgrades to its interior laboratories over the years mirrored the growth of a laboratory and the ongoing evolution of the nuclear weapons it designed.

Building 828 witnessed a gradual evolution to small technical groups or portions of technical groups in need of laboratory space. Eventually, fewer repairs were executed, new groups did not move in, and space stood vacant until the entire building was empty in 1996. Due to the asbestos-laden materials used in the building's original construction, as well as some chemical contamination from work performed there, Sandia's facilities organization scheduled the building for decontamination and demolition. Several proposals were considered for keeping and remodeling the building. Unfortunately, the contamination in the building would have required removing everything but the foundation and rebuilding it from there. The original building would have been lost anyway and the costs were prohibitive. Building 828 was demolished in the late spring of 1999.

\footnotetext{
${ }^{32}$ Digital photograph in SNL Creative Arts CQuest database, unique number 7711.
} 
However, in recognition of Building 828's role as a symbol of Sandia's origins and the fact that it was the only remaining building from the period of Z-Division's initial move to Sandia Base, the west end of the hoist, with its supporting frame, has been saved. It is being incorporated into a monument on the plaza in front of Building 810 in Sandia's Tech Area I. The monument's design evokes the west end of Building 828 and is being constructed in honor of Sandia's $50^{\text {th }}$ anniversary. Thus, Building 828 will still serve as a reminder of Sandia's early history.

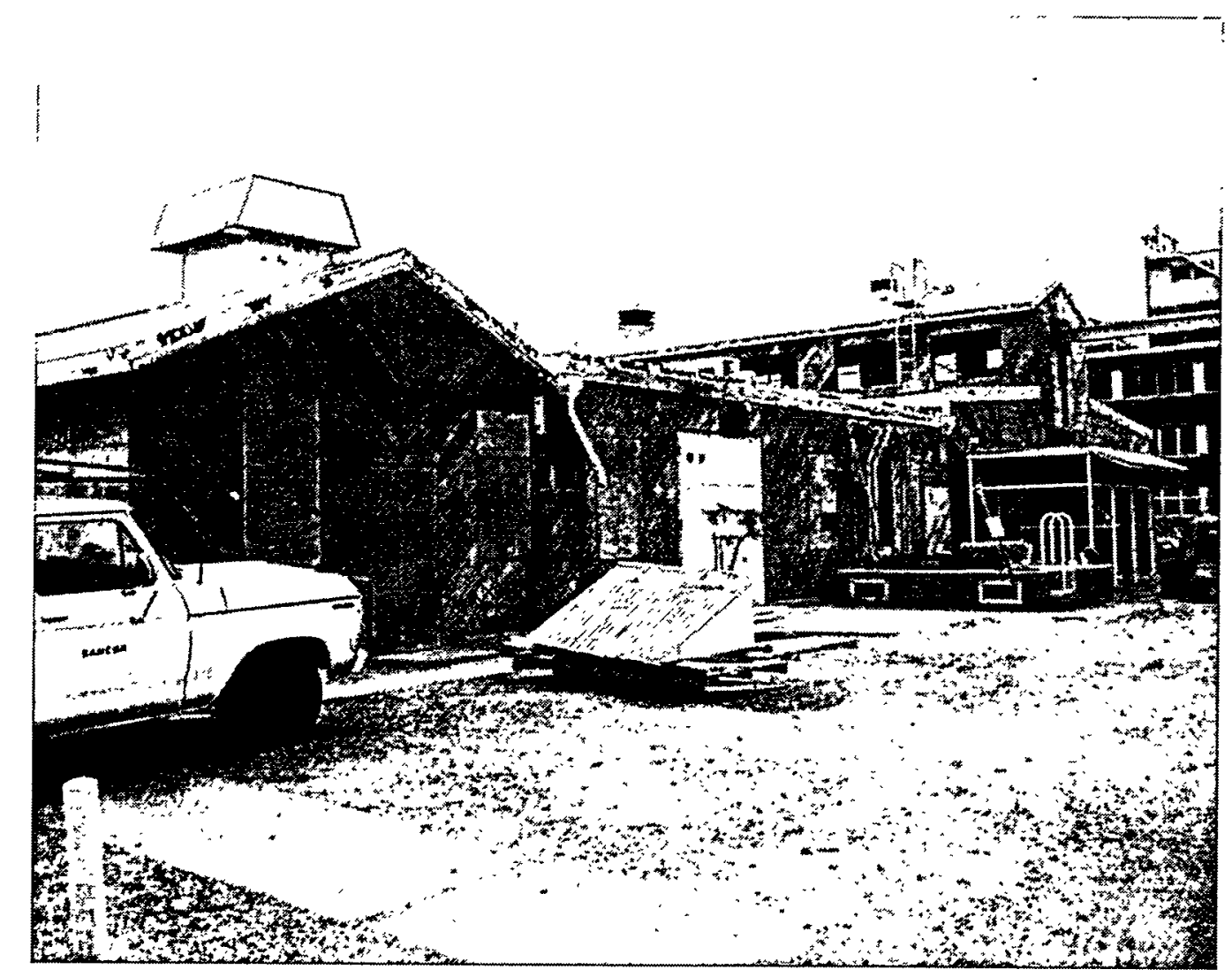

Figure 11. Demolition of Building 828, 1999.33

\footnotetext{
${ }^{33}$ Photograph looking southeast; taken 28 April 1999 by Walt Dickenman. Negative 30208, Still Photo Collection, SNL Archives.
} 


\section{Bibliography}

\section{Archival Sources}

As indicated in the footnotes, the primary archival sources for the history of Building 828 are located in the collections of the SNL Corporate Archives, the SNL Technical

Library's Central Technical File, and the Los Alamos National Laboratory Archives.

\section{Printed Sources}

Alberts, Don E., and Allan E. Putnam. A History of Kirtland Air Force Base 1928-1982. Albuquerque: Kirtland Air Force Base, 1982.

Alexander, Frederic C., Jr. History of Sandia Corporation through Fiscal Year 1963. Albuquerque: Sandia Corporation, 1963.

Furman, Necah S. Sandia National Laboratories: The Postwar Decade. Albuquerque: University of New Mexico Press, 1990.

Hoagland, Steven R. "An Evaluation for National Register of Historic Places Eligibility of Five Sandia National Laboratory Buildings, Kirtland Air Force Base, New Mexico." Submitted to Sandia National Laboratories, Contract \#44-22-61. Albuquerque: Butler Service Group Inc., June 9, 1993.

Johnson, Leland. Sandia National Laboratories: A History of Exceptional Service in the National Interest. Albuquerque: Sandia National Laboratories, 1997.

Professional Resource Management Engineering Group. "Building 828: Renovation Study and Survey." Submitted to Sandia National Laboratories. Albuquerque: Professional Resource Management, Inc., December 4, 1995. 


\section{Appendix}

\section{The Legend of 828}

There is a persistent belief at Sandia that Building 828 was originally built and used for assembling nuclear weapons. It is a belief fed largely by the hoist protruding from the west end of the building's south section. Unused for decades, the hoist serves as a powerful symbol of Building 828 and Sandia's past to longtime employees.

\section{A language problem}

The belief is further bolstered by the way the word "assembly" is used. In a series of interviews and statements by individuals who played a role in Sandia's early history, "assembly" is used in a variety of contexts and thus conveys a variety of meanings. The resulting confusion has made it difficult to determine whether the documentary record of Building 828 is seriously misleading since it omits all mention of any sort of weapon assembly, or if the early discussions of Z-Division's role in assembly have been mistakenly reincarnated as an understanding that 828 was involved in weapon assembly.

Although the Little Boy gun-type nuclear weapon received some research and development attention after World War II, the majority of the early postwar nuclear weapons were implosion weapons, based on the Manhattan Project's Fat Man design. In this design, a sphere of high explosive surrounded a central core of nuclear material. Detonation of the high explosive squeezed the central core of nuclear material, compressing it to a supercritical mass. Introduction of neutrons to the highly compressed core initiated the nuclear chain reaction. However, the non-nuclear components, including the large high-explosive lenses, were assembled and stored separately from the nuclear material and components that turned them into nuclear weapons. Were a weapon to be used, it had to be partially disassembled the nuclear core inserted, and the weapon reassembled. Sealed-pit weapons-weapons with their nuclear components installed during assembly_did not enter the stockpile until 1957.

The nature of these weapons meant that individuals using the word "assembly" during the 1940s and 1950s might mean any of a number of things. Assembly could mean the final assembly before a weapon was used or tested - that is, inserting the nuclear core into the weapon. Alternatively, and most frequently in the case of ZDivision activities, assembly could meant putting all of the non-nuclear piecesincluding the high explosive lenses-together for storage or testing. The latter use also segued into the description of putting together inert mock-ups or prototypes of weapons - that is, assembling a weapon with neither high explosive nor nuclear core. Finally, assembly was also used to refer to putting appropriate pieces together into components, leading up to final assembly of one of the other sorts.

\section{The building's design}

Whatever one takes assembly to mean, however, it is clear there was not much of it going on late in 1945 or early in 1946. The scramble to keep Los Alamos functioning in the face of postwar demobilization and support of the 1946 Crossroads test, the 
construction of new facilities at Sandia Base, and the general lack of a national policy for nuclear weapons, all meant that there was no effort to construct a large stockpile in the year immediately following the war's end.

It is unlikely that mechanical sub-assemblies were being built in Building 828 in 1946. The original drawings of the building are clearly labeled "Mechanical Test Laboratory," and, while this could be taken as an effort to conceal the building's true purpose, other drawings from the period appear to state directly the purposes of the buildings they represent. In addition, the building's design gives no indication that it would have been used for weapon assembly.

In particular, the building contains no internal safety features indicative of high explosive handling. There are no blast walls, assembly bays, or dirt blast berms designed to contain a detonation. Moreover, it is unlikely that even the rashest of decisions regarding high explosive safety would have placed the drafting group in the same building with explosive assembly activities.

The building itself was constructed just 125 feet east of Building T-922 and about as far south of the Base Chapel. The Army's Ordnance Safety Manual of 1945 indicates that a building containing just 1,000 pounds of high explosive would have to be located no fewer than 1,120 feet from another inhabited building. ${ }^{34}$ The thousands of pounds of high explosive contained in each implosion weapon of the period would have required even more distance. Of course, a decision could have been made to suspend such regulations in the name of national need, but every indication is that attention was being paid to safety regulations regarding high explosives.

\section{Other facilities available}

But perhaps the most convincing evidence that Building 828 was not used for weapon assembly lies in the fact that the problem of assembly was being addressed in other areas. As early as September of 1945, an explosives storage and assembly area was envisioned separate from Sandia Base. In a memorandum regarding construction at Sandia, Colonel Seeman, Executive-in-Charge at Sandia, described the required construction as an "Explosives storage and assembly area with connecting roads to Sandia and aircraft loading area at Kirtland Field."35 In December of 1945, Seeman asked the Washington Liaison Office for help in acquiring the land on which to build the storage and assembly area. The land was on the south side of Kirtland Base, south of the runways. The bomb-loading pit was located just at the south edge of the airfield and the assembly area was to be just to the south of it. Plans for acquiring additional land in May of 1946 clearly show the assembly building on the south side of Kirtland Base. ${ }^{36}$

\footnotetext{
${ }^{34}$ United States Army, Ordnance Safety Manual: Regulations Governing the Manufacture, Storage, Loading, and Handling of Military Explosives and Ammunition at Establishments of the Ordnance Department, Army Service Forces, United States Army (Washington, DC: USGPO, 1945), p. 87.

${ }^{35}$ L. E. Seeman to Colonel G. R. Tyler, memorandum, 2 September 1945, Collection A-84-019 18-8, Los Alamos Archives.

${ }^{36}$ Lt. Colonel A. J. Frolich to Colonel L. E. Seeman, memorandum, 29 May 1946, Collection 322 Sandia, Los Alamos Archives.
} 
While the assembly building in the Kirtland ordnance area was being built, weapon assembly continued at Los Alamos. Glenn Fowler, leader of Z-Division's field test group, visited one of the Los Alamos technical areas on 13 October 1945, found it suitable for assembly work, and reported as much to Z-Division head Roger Warner. ${ }^{37}$ In December, Fowler noted that that the first bombs (for field testing) would be assembled at this site. ${ }^{38}$

There is some thought that perhaps weapon assembly was done in a building brought from the Wendover site and reassembled in the Z-Division technical area in December 1945. James Les Rowe, in his accounts of bringing the building to Sandia Base and the work he did there, refers to bomb assembly. Sandia historian Ted Alexander's notes of an interview with Rowe state clearly, "The building was used for assembly of new war reserve weapons, and this activity started in the first or second week of [January] 46." ${ }^{39}$ In a later conversation, however, Rowe indicated that high explosive assembly was not done in the building he brought from Wendover.

Soon after Rowe's arrival at Sandia, he was told to get together a group of Civil Service people and train them in assembling bombs. This he did, and the operation was based at Kirtland Air Force Base. Bombs, after assembly of the high explosive, were then stored in Igloos in the Kirtland ordnance area, e.g. in the arroyo south of the field.

No high explosive assembly was done at Sandia Base, although some live HE units did get sent to Sandia inadvertently. ${ }^{40}$

It is likely that Rowe was assembling inert devices and mock-ups for test drops in the building he brought from Wendover.

Finally, in a 1984 interview, Rowe again made clear that he not only brought a building from Wendover to Z-Division, but also worked on the assembly building in the Kirtland ordnance area. He said he stayed in the military after he was due to leave in February 1946 because he was asked to train assembly crews and proceeded to set up "what they call a final assembly or high assembly building." This was located in the Kirtland ordnance area, not within the Z-Division technical area. ${ }^{41}$

Building P-605, the assembly building in the Kirtland ordnance area, was completed and ready for occupancy 24 May 1946, according to the Post Engineer,

\footnotetext{
${ }^{37}$ Glenn Fowler Engineering Notebook, p. 18, SNL Archives.

${ }^{38}$ Ibid., p. 23.

${ }^{39}$ F. C. Alexander, notes of a telephone conversation with J. L. Rowe, 22 March 1961, p. 2, file: Documents used in Leland Johnson's history, Ted Alexander Collection, Box 2, SNL Archives.

${ }^{40} \mathrm{~F}$. C. Alexander, notes of a telephone conversation with J. L. Rowe, 24 January 1962, p. 1, file: Documents used in Leland Johnson's history, Ted Alexander Collection, Box 2, SNL Archives ${ }^{41}$ James Les Rowe, interviewed by Necah Furman, 18 September 1984, p. 13, Oral History Collection, SNL Archives.
} 
George R. Hawthorne, who also indicated that 828 was nearly complete in June of $1946{ }^{42}$ There was, therefore, no reason to do weapons assembly in Building 828 .

\section{Conclusion}

Building 828 was not used for weapon assembly—either high explosive lens assembly or nuclear core insertion. Other facilities were available and used for that purpose. All evidence indicates that 828 was designed and used as a mechanical test laboratory. As such, it represents the core of Sandia's early ordnance design mission.

${ }^{42}$ George R. Hawthorne to Commanding Officer, U.S. Engineers, Santa Fe, Attention: Lt. Col. W. A. Stevens, 3 June 1946, Collection A-84-019 18-8, Los Alamos Archives. 


\section{DISTRIBUTION}

1 MS 0165 John German, 12640

2 MS 0184 Susan Lacy, DOE/KAO

30 MS 0612 Myra O’Canna, 4912

26 MS 0612 Rebecca Ullrich, 4912

2 MS 0632 John Hogan, 9407

1 MS 0908 Georgianne Peek, 7833

2 MS 0936 Carol Meincke, 7810

30 MS 1042 Joan Harris, 7575

1 MS 1231 Roger Hagengruber, 5000

1 MS 1233 Irene Dubicka, 9731

1 MS 9018 Central Technical Files, 8940-2

2 MS $0899 \quad$ Technical Library, 4916

1 MS 0612 Review \& Approval Desk, 4912 For DOE/OSTI 